\title{
An exploration of Peter Singer and Richard Posner's ethical arguments regarding the moral status of animals, with a specific focus on the use of animals for the consumption of food
}

\author{
Jade Eloise Eva Watts, Northumbria University, $4^{\text {th }}$ Year MLaw
}

The use of animals for the consumption of food is becoming a focus in recent times, due to environmental and animal welfare concerns. There has been an increase in research around the environmental concerns of the mass scale of the production of meat, with meat production in 2018 estimated at 330.51 million metric tons. ${ }^{1}$ In the UK alone, 182,000 cows were slaughtered in November $2018^{2}$ and 108.4 million broiler chickens were slaughtered in October 2018. ${ }^{3}$ Many animal welfare groups argue against the inhumane conditions animals go through before they reach our plate. ${ }^{4}$ Due to this, a record number of people are reducing meat and animal product consumption, with some research indicating over 1.6 million people in the UK are vegan or vegetarian in $2016 .^{5}$ With the questions and concerns around eating meat becoming so prominent today, it seems like the perfect time to revisit the philosophical arguments. This article will explore the global scale of using animals for the consumption of food, through the ethical arguments advocated by philosopher Peter Singer, author of Animal Liberation, ${ }^{6}$ of affording animals an equal moral status to humans. It will then consider the arguments advanced by Judge Richard Posner, as a tool to offer a critical analysis of Singer's ideas.

\footnotetext{
1 Satistica, Production of meat worldwide from 2016 to 2018 $<$ https://www.statista.com/statistics/237644/global-meat-production-since-1990/> Accessed $13^{\text {th }}$ January 2019

2 DEFRA, United Kingdom Slaughter Statistics - November 2018, 13 ${ }^{\text {th }}$ December 2018 $<$ https://assets.publishing.service.gov.uk/government/uploads/system/uploads/attachment data/file/763961 Lslaughter-statsnotice-13dec18.pdf> accessed $14^{\text {th }}$ January 2019

${ }^{3}$ DEFRA, United Kingdom Poultry and Poultry Meat Statistics - October 2018, 22 ${ }^{\text {nd }}$ November 20182018 $<$ https://assets.publishing.service.gov.uk/government/uploads/system/uploads/attachment data/file/758289 /poultry-statsnotice-22nov18. pdf> accessed $14^{\text {th }}$ January 2019

4 For example, please see Viva, Slaughter Fact Sheet: Their Last Moments, May 2017 <https://www.viva.org.uk/resources/campaign-materials/fact-sheets/slaughter-factsheet-their-last-moments> accessed $14^{\text {th }}$ January 2019

${ }^{5}$ The Vegan Society, There are three and a half times as many vegans as there were in 2006, making it the fastest growing lifestyle movement, $17^{\text {th }}$ May $2016<$ https://www.vegansociety.com/whats-new/news/find-out-howmany-vegans-are-great-britain $>$ accessed $14^{\text {th }}$ January 2019

${ }_{6}^{6}$ Peter Singer, Animal Liberation (2nd edn, Pimlico 1995)
} 


\section{Volume 1 Issue 1 Student Journal of Professional Practice and Academic Research}

Peter Singer, 'father' of the animal liberation movement, ${ }^{7}$ advocated for the application of a somewhat Bentham-inspired, consequential, utilitarian approach to the understanding of the moral status of animals. Jeremy Bentham, a utilitarian philosopher, famously stated: "the question is not, can they reason? nor, can they talk? but, can they suffer?". 8 Singer acknowledges the notion that human beings are believed to be inherently superior and more valuable than any animal. He stated, quite simply, that if a conflict arose between the interests of a human and the interests of an animal, 'we' would always triumph. ${ }^{9}$ Instead, Singer proposes the argument that "all animals are equal" ${ }^{10}$ and belong on an equal footing; this has been referred to as the 'principle of equal consideration of interests'. ${ }^{11}$ Singer explained that the feature, which entitles an animal to have their interests valued equally, lies not with its existence as a 'homo sapiens', nor its intelligence, rationality or self-awareness; rather, it is dependent upon sentiency: the ability to feel pain and pleasure; if it were to depend on anything narrower, it would be arbitrary. ${ }^{12}$ In short, Singer argued that the pain of an animal is equal to, and as important as, the pain experienced by a human. ${ }^{13}$ He stated that the ability of humans to develop language, self-awareness and autonomy cannot be the distinguishing feature that divides the 'insuperable line, ${ }^{14}$ between all human beings and animals. This is because there are human beings that are not capable (such as an infant), nor will they ever be capable (such as a child born with a serious brain injury) of developing these skills; yet, they are still afforded moral concern. Singer stated that this is a product of speciesism (as coined by Richard Ryder). ${ }^{15}$ It is essentially the idea that we, as humans, participate in the practice of valuing and privileging humans over any other animal, and use the fact that they are of a different species as justification for their exploitation. Singer compared this to the ideology embodied by those who are sexist or racist; the fact that some individuals are not of the same race does not entitle us to exploit them, nor to discount their interests. ${ }^{16}$

\footnotetext{
${ }^{7}$ Ibid (Title of chapter 1 )

8 Jeremy Bentham, An Introduction to the Principles of Morals and Legislation (1st edn, Dover Publications 1989)

${ }^{9}$ Peter Singer, Animal Liberation (2nd edn, Pimlico 1995) 1- 23

${ }^{10}$ Tom Regan and Peter Singer, Animal Rights and Human Obligations (2nd edn, Prentice Hall 1989)

${ }^{11}$ Peter Singer, Animal Liberation (2nd edn, Pimlico 1995) 7

12 Ibid 1- 23

$13 \mathrm{Ibid}$

$14 \mathrm{Ibid}$

15 Ibid 9; For information on speciesism see Richard Ryder, Speciesism Again: the original leaflet <http://janegerhard.com/wp-content/uploads/2017/01/Speciesism-1970.pdf> accessed $13^{\text {th }}$ January 2019

${ }^{16}$ Ibid 9
} 


\section{Volume 1 Issue 1 Student Journal of Professional Practice and Academic Research}

It is useful to understand the practical application of his principle of equal consideration, especially in the context of farming animals for the production of food, which Singer notes is a matter of international concern. Singer has discussed the fact that this industry is vastly increasing in terms of global demand, and has led to the unnatural growth of the population of some farm animals as a result, such as pigs. ${ }^{17}$ He soberly recounts the reality of the lives of pigs which are used for meat, stating that they live in extreme confinement, in which these complex, intelligent and sentient animals are kept on bare concrete, without any basic comforts or mental stimulation, ${ }^{18}$ which causes severe mental stress and frustration. ${ }^{19}$ In short, Singer asserts that, in an industrialised society, where an adequate diet can be easily sourced, the "flesh of an animal is a luxury": their suffering is endured, simply because it pleases human taste buds, not because it offers better health or longevity. ${ }^{20}$ Singer explains that the principle of equal consideration does not allow for the major interests of an animal (such as a pig's life and well-being) to be sacrificed for the minor interests of another (such as a human's taste buds). ${ }^{21}$ Thus, in order to put an end to speciesism, and equally account for the interests of all factory farmed animals, "we must stop these practices". By this, he means that we must stop buying meat and other animal produce. ${ }^{22}$ He acknowledges to the reader that this may be difficult, but proposes that the decision will be no "less difficult than it would have been for a white southerner to go against the values of his community and free his slaves”. ${ }^{23}$ He asks, if we cannot abstain from buying these products, thus funding the suffering of millions of farmed animals, how can we pass judgement on those slave-holders who could not change their own way of living? ${ }^{24}$ Whilst being a somewhat uncomfortable comparison, or rather, an uncomfortable realisation, this is a particularly powerful and persuasive moment in his book, 'Animal Rights and Human Obligations'. ${ }^{25}$ The abstinence in buying meat and other animal products is something which we now see happening throughout the Western world. People are becoming more likely to question where their food has come from and the conditions which

\footnotetext{
17 Peter Singer and Miyun Park, 'The Globalization of Animal Welfare: More Food Does Not Require More Suffering' (2012) 91 Foreign Affairs.

18 Peter Singer, Animal Liberation (2nd edn, Pimlico 1995) 119 -128

$19 \mathrm{Ibid}$

${ }^{20} \mathrm{Ibid}$

${ }^{21}$ Peter Singer, In Defense of Animals:The Second Wave (2nd edn, Blackwell Publishing 2006) 20-22

22 Ibid

${ }^{23}$ Tom Regan and Peter Singer, Animal Rights and Human Obligations (2nd edn, Prentice Hall 1989) 152

24 Ibid 152

${ }^{25}$ Ibid 152
} 


\section{Volume 1 Issue 1 Student Journal of Professional Practice and Academic Research}

the animals went through to get to their plate. The decision to stop eating meat has now become less difficult, with the rise of education in farming conditions and campaigns, such as Veganuary. ${ }^{26}$

Richard Posner remarks that Singer proposes a "lucid and forceful argument," ${ }^{27}$ and agrees that humans are not inherently more valuable or superior than any other animals. However, Posner stated that, whether we like it or not, humans will always be speciest, and we will always discriminate in favour of our own kind. He argued that a duty is not imposed on humans to treat other animals equally, on the basis that they are a member of a universal community that comprises of those who can feel pain. ${ }^{28}$ He simply declares that, like other animals, we 'prefer our own'. He exemplifies this by stating that Americans, for example, are generally less sympathetic to pain endured by foreigners, never mind that experienced by animals. He argued that this preference does have normative significance, and this is because it is reflective of a basic moral intuition. ${ }^{29}$ However, Singer expresses concern over this argument; citing the grave tragedies that have occurred as a result of reactions based on 'moral' intuitions, such as Nazi law, which was said to be reflective of the "healthy sensibility of the people". ${ }^{30}$ Singer questions why we have to give such reactions any probative weight, arguing that, whilst people may share this common reaction of speciesism, it does not mean that this is the one which they ought to have. Singer stated that if this is Posner's logic, he must therefore defend those who are racist to other ethnic groups, on the grounds that their moral intuition has normative significance. ${ }^{31}$

A focal point of Posner's criticism of Singer was that his ethical arguments were simply obsolete, in the presence of our overarching moral intuition, which he believes is incapable of being disregarded. To demonstrate this, he expands on Singer's argument that there are in fact animals which possess greater capabilities than humans with severe mental difficulties, such as those in the late stages of Alzheimer's. He explains that, morally, it would be very difficult

\footnotetext{
${ }^{26}$ For more information, please see <https://veganuary.com>

27 Peter Singer and Richard Posner, 'The Debate between Peter Singer and Richard Posner via email' (Utilitarian.net, 2001) <https://www.utilitarian.net/singer/interviews-debates/200106--.htm (accessed 11 April 2018)

28 Peter Singer and Richard Posner, 'The Debate between Peter Singer and Richard Posner via email' (Utilitarian.net, 2001) <https://www.utilitarian.net/singer/interviews-debates/200106--.htm (accessed 11 April 2018)

$29 \mathrm{lbid}$

30 Ibid

31 Ibid
} 


\section{Volume 1 Issue 1 Student Journal of Professional Practice and Academic Research}

to consider the murder of a human to be of equal significance to the killing of an elderly dog. ${ }^{32}$ However, Singer argued that this stance is not predicated on a notion of moral intuition, but rather as a result of self-preservation borne out of concern about how they themselves could be treated in future, should they develop such a condition. Nevertheless, Posner argued that, even if the life of a human is said to be only 100 times more valuable than one chimpanzee, for example, it would still be contrary to our deepest instincts and intuition to sacrifice the life of one human, if it meant saving 101 chimpanzees. $^{33}$

Singer advanced his philosophical argument to Posner in an exchange that took place in Slate Magazine in 2001, in the hope of persuading him that there is an ethical case for changing the moral status of animals, to allow them to have their interests considered as equal to those of a human. However, Posner stated that, whilst we must have a greater commitment to reducing the suffering of animals, especially those raised for food, he argued that the most effective way in which we can bring about real progression for the animal rights movement is not by reducing the value of a human life to the status of an animal, whilst approaching the subject in a philosophical manner, but rather, through facts. ${ }^{34}$ Posner argued that it is not so much an ethical case but a factual one, as the more factual information we can obtain about animals and their treatment, the more we can encourage a shift in our moral intuition to a greater empathetic response to their suffering, and in turn commit to a more serious consideration of the alternative, low-cost methods for farming animals for human consumption.

Singer, in Animal Liberation, explains that our relationship with non-humans is founded on speciesism, which has resulted in gross exploitation, due to the discounting of their interests. However, the question that Singer perhaps fails to address is, why are we so prepared to accept this moral asymmetry? Yes, he explains that it is speciesism that has made us biased, but what is holding the prejudices resulting from speciesism so strongly in place? This is what Posner's concern is with Singer's argument, which he believes to be a very radical ethical vision. Posner contended that Singer has failed to recognise how crucial our moral intuition is to the answering of this question; arguing that the spreading of compelling factual information, rather than philosophical arguments, is our leading hope for being able to inspire a change in our moral intuition, with regards to how we respond to the standard and treatment of animal welfare. Whilst Singer agrees that Posner undeniably offers a pragmatic approach (perhaps reflective

\footnotetext{
32 Ibid

33 Ibid

34 Ibid
} 


\section{Volume 1 Issue 1 Student Journal of Professional Practice and Academic Research}

of his role as a judge), he nevertheless defends the role that a "little philosophy" 35 can have, and has had, in the pursuit of persuading his readers to take a more serious look into the status and treatment of animals.

In conclusion, it is obvious why Singer is referred to as the founder of the modern philosophical animal rights movement, ${ }^{36}$ as he has made invaluable contributions to our understanding of animal welfare. The arguments advanced by both Singer and Posner have offered thoughtprovoking and pragmatic options as to how best we can take active steps to relieve the suffering of animals and improve the methods involved in farming animals for human consumption. Singer favoured a philosophical approach, arguing that the interests of animals should be considered equal to that of humans. Therefore, his view of the farming of animals for food is simple, in order to adhere to this principle of equal consideration, and to defeat speciesism: stop supporting the meat industry and other animal farming practices. However, Posner is very critical of this approach, arguing that Singer has failed to see how radical this ethical argument is when you consider its practical implications. Posner ultimately concludes that, in order to allow for development and invigoration of the law regarding this epidemic, we should address this situation, not through forceful philosophical arguments, but rather through facts that can stimulate a more pro-active approach, which he states were the most persuasive parts of Animal Liberation. However, I think it would be unfair to disregard the role which philosophy has taken, and will always take, in the progression of the welfare of animals; to this end, I find myself favouring an approach that allows for the combination of both philosophical and factual efforts in the pursuit of better treatment of farmed animals.

\footnotetext{
$35 \mathrm{Ibid}$

${ }^{36} J u$ lian Franklin, 'Killing and Replacing Animals.' (2007) 2 J Animal L \& Ethics 77
} 